\title{
Una perspectiva global de las fiestas en honor a Rosa de Lima en el mundo hispano del siglo XVII ${ }^{1}$
}

\author{
Ramón Ojeda Corzo ${ }^{2}$
}

Recibido: 19 de diciembre de 2019 / Aceptado: 21 de noviembre de 2020

Resumen. Este trabajo tiene como objetivo reforzar el estudio del catolicismo global moderno, observado como un poder ideológico, con pretensiones de alcanzar una uniformidad cultural a lo largo del imperio hispánico. Para ello, se han analizado las múltiples fiestas de beatificación y canonización de Rosa de Lima, desarrolladas entre 1668 y 1671, desde una perspectiva global. La clave del análisis reside en observar la circulación y movilidad, tanto humana como material, que permitieron la expansión de una devoción criolla limeña y el desarrollo exitoso de las respectivas ceremonias, en el orbe católico del siglo XVII.

Palabras clave: Rosa de Lima; fiestas; beatificación; canonización; estudios globales; catolicismo moderno; agentes; siglo XVII.

\section{[en] A Global Perspective of the Festivities in Honor of Rose of Lima in the Hispanic World of the 17th Century}

\begin{abstract}
The objective of this article is to reinforce the study of modern global Catholicism, seen as an ideological power with pretensions of achieving cultural uniformity throughout the Hispanic Empire. To this end, the numerous festivities of beatification and canonization of Rosa of Lima that took place between 1668 and 1671 have been analyzed from a global perspective. The key to the analysis lies in observing both the human and material circulation and mobility that allowed for the expansion of a Creole devotion in Lima and the successful development of its respective ceremonies within the Catholic orb of the $17^{\text {th }}$ century.
\end{abstract}

Keywords: Rose of Lima; Festivities; Beatification; Canonization; Global Studies; Modern Catholicism; Agents; $17^{\text {th }}$ Century.

Sumario. 1. Introducción. 2. Un firmamento alumbrado de santidad. 3. Conclusiones. 4. Referencias bibliográficas.

Cómo citar: Ojeda Corzo, R. (2021) "Una perspectiva global de las fiestas en honor a Rosa de Lima en el mundo hispano del siglo XVII", en Revista Complutense de Historia de América 47, 137-159.

1 Mis agradecimientos van dirigidos a mi tutor, Federico Palomo, por su constante ayuda, confianza y atención para la publicación de este texto, cuyas líneas se trazaron con la ilusión y motivación propia de un joven investigador. A mi amiga Paula Becerra Fuello, arqueóloga (CSIC-US), por su revisión, y a toda mi familia, mi indestructible pilar de apoyo.

2 Doctorado en Historia y Arqueología, Universidad Complutense de Madrid (España).

E-mail: ramojeda@ucm.es 


\section{Introducción}

Doña Isabel Flores de Oliva nace en Lima un 20 de abril de 1586, hija de Gaspar Miguel Flores y de María de Oliva, un matrimonio criollo. Así lo narran las primeras páginas de una de sus hagiografias: "Nació de padres christianos, cuyas virtudes hicieron mayor la nobleza oculta que heredaron; siendo la hermosa niña, primer escalón del premio que gozan"’3. La vida de Isabel Flores, a caballo entre el reinado de Felipe II y Felipe III, bien podría haber sido la de una súbdita más de la extensa Monarquía Hispánica. No obstante, sus singulares pasos por la esfera religiosa, tomando como referencia la vida de los santos europeos de su Orden, santo Domingo de Guzmán y santa Catalina de Siena, la llevarían a conseguir un altar en el cielo católico como modelo de santidad americana ${ }^{4}$.

Hablar de Rosa de Lima no es fácil, y menos tras la larga producción historiográfica que su figura ha generado, debido a la profusa extensión geográfica que alcanzó su proceso de canonización en el siglo XVII. En el presente estudio se van a analizar las ceremonias católicas, de beatificación y canonización, realizadas en las principales ciudades hispánicas. Observadas desde una perspectiva global ${ }^{5}$, el catolicismo moderno adquiere la connotación de un poder ideológico-cultural, vector de conexión entre los diversos territorios imperiales ibéricos. El cruce de diversas fuentes con algunos trabajos sobre estas fiestas, permitirá poner en relación distintos estudios aislados sobre las mismas, que no habían sido comparados bajo una visión de conjunto, a través de una historia cruzada y conectada de todos los eventos religiosos que se llevaron a cabo, desde Roma hasta Manila.

A su vez, la necesaria relectura del fenómeno festivo moderno, -en la línea de lo que han propuesto Fernando Checa Cremades y Laura Fernández $-^{6}$, bajo el prisma de lo cultural y lo global, nos mostrará a la Monarquía Hispánica como un espacio que va más allá de límites político-territoriales, acotados tradicionalmente por la historiografía. El estudio aporta la imagen de una corona hispánica festiva, ostentosa e influyente, frente a un contexto de desequilibrio político con la ruptura de la Unión Ibérica en 1668 -mismo año de la beatificación de Rosa de Lima-, y de crisis financiera en la segunda mitad del siglo XVII. Junto a ello, este triunfo católico plasma la imagen propagandística de una Monarquía cohesionada y hegemónica bajo la estructura de un policentrismo territorial imperial. Sobre esta idea ya han hecho hincapié trabajos en la línea de la globalización devocional ${ }^{7}$, como los estudios de las canonizaciones de san Ignacio de Loyola y san Francisco Javier ${ }^{8}$. En pocas palabras, nos situaremos ante un juego de interacciones e influencias culturales entre centros urbanos, que escapa de la premisa de perpetuo dominio en un eje cerrado metrópoli-periferia imperial, para convertirse en un entramado

\footnotetext{
Vargas, 1659: 2.

Véase Flores Araoz, 1995. Sabatini, 2012.

Véase Checa Cremades- Fernández-González, 2015.

Véase Ditchfield, 2009.

Véase Betrán Moya, 2010.
}

Este trabajo adopta la perspectiva de lo global que elaboró Gruzinski, 2010.En su estudio se plasmó cómo la reciente primera mundialización, llevada a cabo por la expansión territorial de las coronas de Portugal y Castilla en el siglo XV, condujo progresivamente a un mundo conectado y en constante interacción en todos los ámbitos. Para un primer acercamiento, véase también Conrad, 2017.Respecto al estudio del catolicismo altomoderno desde una perspectiva global véase Ditchfield, 2010; Hsia - Palomo, 2020; Cardim - Herzog - Ruíz Ibáñez - 
de flujos multidireccionales, donde los territorios de ultramar adquieren un papel protagonista 9 .

\section{Un firmamento alumbrado de santidad}

Lima, 24 de agosto de 1617, fallece Rosa de Lima en casa del contador don Gonzalo de la Maza. La Ciudad de los Reyes se hace eco, el pueblo y las autoridades acuden a velar su cuerpo. Sus milagros eran conocidos por la muchedumbre y la élite criolla aprovechó el momento. La clave idónea para la representación de su identidad americana y reivindicar su papel dentro del imperio. El virrey peruano, Francisco de Borja y Aragón, junto al arzobispo de Lima, Bartolomé Lobo Guerrero, comienzan a realizar encuestas al pueblo para certificar ante Roma la devoción popular. Informes y comisiones desde Roma se mueven entre El Callao y el Tíber ${ }^{10}$. Los miembros de la Congregación de Ritos en Roma analizan y retrasan el proceso apostólico, desde el fallecimiento de la religiosa en 1617 hasta 1668 cuando se le otorga la beatificación. En ese periodo de cincuenta años proliferaron las hagiografías de la religiosa limeña, que comienzan a ser escritas con relativa celeridad tras su muerte ${ }^{11}$.

Los dominicos en cada sede del orbe y en cada misa oficiada, van instando a los fieles hacia el conocimiento de la vida de su prodigiosa terciaria limeña. En 1659, el dominico Vargas Machuca saca a la luz en Sevilla, Puerto y Puerta de Indias, una hagiografía de gran calibre, con licencias adquiridas en la misma capital hispalense y en Lima. El Viejo Mundo va empapándose de la nueva imagen de ultramar y pequeñas palpitaciones devocionales locales se van intuyendo desde Lima a Roma, desde Sevilla a Madrid. Así, en 1665 el dominico inglés Leonardo Hansen se encargaría de establecer la vida de la religiosa con tinta y papel, para que se conociese en Roma las hazañas de aquella mujer limeña ${ }^{12}$. Dos años más tarde, en 1666, el dominico Ferrer de Valdecebro logra sacar a la luz en Madrid otra hagiografía que hiciese de la religiosa dominica una vecina más de la Villa y Corte imperial ${ }^{13}$, bajo el amparo del confesor jesuita de la reina regente, Juan Everardo Nithard ${ }^{14}$. El autor esperaba con ansias los acontecimientos que darían arranque al mayor triunfo y gloria de su religión: "Esta relación se hizo el año pasado de 63 , ajustose el de 65 el punto de haber tenido las virtudes en grado heroico, y esperamos por horas la determinación de su santidad, en su beatificación la del santísimo Pío V, y la de sor Margarita de Castelo, la canonización de san Luis de Beltrán, y la de san Alberto Magno, todos de mi sagrada religión"15.

\subsection{Fiestas de beatificación y patronazgo entre 1668 y 1670}

Roma fue la primera en conocer en profundidad el fenómeno devocional en torno a Rosa de Lima y la primera capital del orbe católico en celebrarla. Durante la etapa

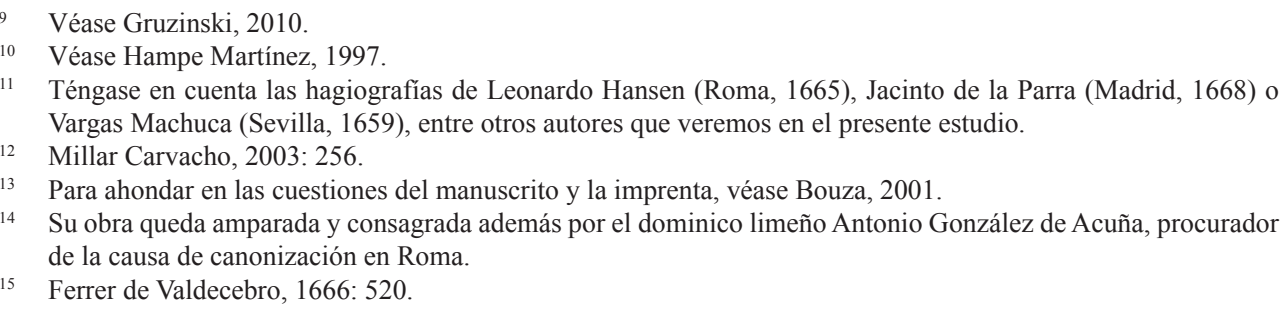


final del desarrollo de la causa de Rosa de Lima, la Orden dominica ya contaba con un gran prestigio y poder en la corte romana bajo la protección de la corona española, a través de sus embajadores en la Ciudad Eterna ${ }^{16}$. Gran parte del éxito alcanzado por los dominicos en el proceso de canonización se debió a la influencia de personalidades en Roma como el maestro general de la Orden, Juan Baptista Marinis. Su experiencia en procesos de canonización de otros santos dominicos ${ }^{17}$; los contactos con la corte madrileña de Felipe IV y la connivencia con el pontífice Clemente IX, lo convirtieron en una figura de enlace entre la corte madrileña y romana, así como el principal artífice del proceso junto a su sucesor, fray Juan Tomás de Rocabertí. La ceremonia inaugural de beatificación tuvo lugar en San Pedro, enclave primigenio en festejar a la beata peruana y un referente modélico para el resto de fiestas celebradas en el orbe.

Tocó la Fama su Trompa, y viose la que despreció aplausos de una ciudad en todo el Orbe celebrada [...] y aunque asistiendo en Lima, ninguno fuera della conoció; oculta en breve sepulchro, el Perú la invoca, México la venera, España la admira, Roma la celebra [...] Y tú, Lima, logra sin dilación de tiempos el que sea rigor, no piedad, el crédito de tu Patrona; vocéela Roma, festéjela el Perú Sancta ${ }^{18}$.

El convento de Santa Sabina fue centro de una gran noticia para el Perú y la élite criolla. El 12 de marzo de 1668 el papa Clemente IX acababa de firmar, en dicho convento, el breve de la beatificación de Rosa de Lima. Desde el 15 de abril y hasta el 10 de junio, Roma estuvo de fiesta. Los festejos son descritos por don Francisco de Córdoba y Castro (Festivos cultos, célebres aclamaciones, Roma, 1668) ${ }^{19}$ y el doctor Diego F. de Albornoz (Breve relación, Granada, 1668). Los festejos de la beatificación, acaecidos entre el 15 de abril y el 12 de mayo de 1668, fueron los que proliferaron en las primeras relaciones de fiestas. Festejar la beatificación de Rosa de Lima en la propia basílica vaticana fue voluntad del papa Clemente IX. Dicha ceremonia contó con la presencia física de dominicos limeños en Roma, como el teólogo fray Antonio González de Acuña. Este dominico peruano fue enviado a Roma como procurador general de la provincia limeña de Santo Domingo. A su paso por Madrid se encargó de convencer al rey Felipe IV de escribir al nuncio para respaldar el proyecto de la Orden. Llegó a Roma en 1660 con cartas del rey, alcanzando una férrea influencia en la Sede Pontificia como procurador de la causa de canonización en la Ciudad Eterna ${ }^{20}$. Al mismo tiempo ejerció como promotor de obras literarias para la divulgación de la vida de Rosa de Lima ${ }^{21}$. Sus escritos se añaden al extenso listado de autores de hagiografías de Rosa, publicando su obra en Roma en $1671^{22}$. Esta presencia y agencia

\footnotetext{
16 Carrió-Invernizzi, 2008: 123.

17 Encargó a fray Juan Tomás de Rocabertí, sucesor en el generalato en 1670, como procurador de canonización de san Luis de Beltrán y la beatificación de Pío V. Ambos tenían experiencia previa y buena sintonía con el pontificado. Callado, 2007.

18 Vargas, 1659: 91-93.

19 Obra dedicada por el autor al sobrino del pontífice Clemente IX, el cardenal nepote Tomás Rospillosi, del cual el autor se presenta al servicio de esta autoridad religiosa como "su más humilde y devoto criado". Córdoba, 1668: f. $2 \mathrm{v}$.

20 Graziano, 2002. La influencia de este fraile limeño ha sido analizada en la tesis sobre Rosa de Lima y las fiestas de beatificación de Lima y México recientemente publicada. Véase Arias, 2019: 66-68; Graziano, 2004.

21 Fagiolo, 1997: 455. Como procurador de las fiestas, este dominico limeño consagró y promovió la publicación de obras como Ferrer de Valdecebro, 1670.

22 González de Acuña, 1671.
} 
cultural peruana en la corte romana se constata no sólo físicamente en la Basílica de San Pedro, sino también con representaciones simbólicas, como el escudo de armas de Lima en su fachada, o en el interior del templo con la representación alegórica e idealizada de los paisajes americanos del Perú, en el programa iconográfico que narraba las hazañas de la religiosa para los fieles. Un programa orquestado por González de Acuña, que debió transmitir sus conocimientos del mundo americano a los artistas, pues sin haber conocido nunca Lima, representaron el río Rímac en sus obras, retratando sus conocimientos aproximados del contexto geográfico y urbanístico en el que acaecieron las bienaventuranzas de la religiosa dominica ${ }^{23}$.

Ver amanecer la basílica de San Pedro debió ser impactante para los habitantes romanos. Las puertas principales ostentaron las armas del pontífice, en el centro se situaban las armas del rey católico, Carlos II, y las de la ciudad de Lima entre dos columnas custodiadas por el "Plus Ultra". Se plasmarían en grandes lienzos toda la vida de la religiosa dominica, milagros y virtudes. La iglesia se transfiguró con colgaduras de terciopelos e hilos de oro y plata, perfumadores también del metal plateado y todo ricamente enjoyado para un nuevo miembro celeste. Seis tabladillos se añadían a la decoración, donde en cada uno había un coro de "los más escogidos músicos de Roma". En ellos se estrenaron muchas obras musicales como la de Horacio Beneboli, maestro de capilla de San Pedro. A ello se le unió la elevación, en el espacio de la gran tribuna, de un majestuoso teatro, en cuyo testero se podía admirar a Rosa de Lima en un "cuadro de 10 palmos de alto y 15 de largo, obra de Lázaro Baldi"24. Uno de los lienzos resultó ser particular, pues en la extremidad de aquel teatro estaba el altar con otro cuadro de la religiosa dominica, triunfante, con el niño en brazos, "y a los pies de la figura principal estaban los pueblos del Perú, y Provincias circunvecinas hincados de rodillas, que con humilde reconocimiento la adoraban" 25 . El espacio central de la basílica quedaba presidido por una representación alegórica del pueblo peruano. Una clara expresión y propaganda de la identidad criolla al pueblo romano y las autoridades europeas allí presentes. Así quedó custodiada en tinta la imagen de la concurrencia en la basílica:

No puede explicarse el gran concurso que hubo en San Pedro, así por la mañana a la función referida, como a la tarde a las vísperas visitando las imágenes de la bienaventurada Rosa, que todo el día estuvieron patentes: y su Santidad fue servido, por multiplicar los favores, de visitar también la Basílica, acompañado de Príncipes, y Prelados, a quien se repartieron retratos, y compendios de la visa de la Santa; y lo mismo se hizo en todo el pueblo, holgándose todos, y nos de leer sus acciones maravillosas, y otros de mirar la devotísima efigie de la Esposa de Christo; siendo tanto el concurso de Embajadores, Príncipes, y Princesas, que pocas veces le ha visto Roma tan calificado, y numeroso, siendo común el aplauso de nobles, y plebeyos ${ }^{26}$.

Al comenzar la ceremonia se descubrió una imagen de bulto de la dominica limeña y se mostró a su vez el cuadro descrito de la puerta mayor. En ese momento se

\footnotetext{
Córdoba, 1668: 17-26.

Albornoz, 1668: f. 6r.

Ibídem: f. $5 \mathrm{y}$.

Ibídem: ff. $8 \mathrm{r}-8 \mathrm{v}$.
} 
arrodillaron los cardenales y hubo festejo de cajas y trompetas, artillería, bombardas y más de trescientos morteretes en la plaza de San Pedro, respondiendo otros muchos en la plaza del Embajador, la de Santiago de los Españoles, la de Santa María sopra Minerva, la de San Sixto, el convento de Santo Domingo, en Santa Catalina, la Magdalena, la Humildad y en todos los conventos de la misma Orden ${ }^{27}$.

El segundo foco festivo se llevó a cabo en la iglesia dominica de Santa María sopra Minerva. El 13 de mayo de 1668, los dominicos de dicha iglesia vuelven a lucir fachada con lujo de detalles efímeros, con una imagen de la beata en su interior y nueve cuadros representando su vida. Quien hubiese acudido al templo contempló al embajador español, el marqués de Astorga, y le vio el rostro a la sobrina del papa, doña Catalina Rospillosi. Suerte tuvieron todos los fieles asistentes de recibir estampas y medallas de la dominica peruana. Entre damascos y tapices se podía contemplar la escultura de mármol de la dominica dormida, que iba a ser enviada al Nuevo Mundo, la cual disfrutaron los romanos por unos instantes ${ }^{28}$. Todas las órdenes representadas en la iglesia se quisieron hacer eco de las octavas, hasta el propio Juan Baptista de Marinis, maestro general dominico, estuvo presente. Según datos relativos al público espectador aportados por Córdoba y Castro, se habría contado, aproximadamente, con la asistencia de más de nueve mil personas en San Pedro y unos 1500 asistentes en Santa María sopra Minerva.

Finalizados los actos del octavario un domingo, con el clásico Te Deum, a la noche hubo artificios de fuego "cuyos festivos humos prometen Superiores Luces, que espera haber en su canonización la Religión de Predicadores"29. Se llevaron a cabo otras fiestas en el Colegio Romano de la Compañía de Jesús el 23 de mayo de 1668. A ella asistieron personalidades de alto rango eclesiástico que deleitaron la música, los coros, la oratoria y la poesía recitada por tres nobles alumnos del Seminario romano. El 10 de junio tendría lugar el festejo de la beatificación en la iglesia de Santiago de los Españoles, impulsada por don Juan A. Otalora, gobernador de dicha iglesia y de la "nación española". En el templo se mostraba un cuadro con la imagen de Clemente IX sentado, otorgando a Carlos II "la obediencia rendida de las Indias" ${ }^{30}$. Las demostraciones festivas comenzarían el 9 de junio, noche en la que se llevaron a cabo espectáculos simultáneos de fuegos artificiales en todas las plazas romanas, como previo aviso y pregón a la población de los actos festivos en la iglesia de Santiago ${ }^{31}$. En las octavas predicó su sermón el padre jesuita Nicolás Martínez (Oración panegírica, Roma, 1668), alzando a la corona española como principal causa de este triunfo por su dominio y evangelización de América:

Oi es el día, fieles, en los altísimos y secreto juicios de la Divina Providencia destinado a la gloria felicísima de nuestra España[...] Que la España fuese señora de un nuevo Mundo, al sol descubierto solamente, a toda el arte de navegar oculto, lo quiso Dios, cuyo querer es obrar ${ }^{32}$.

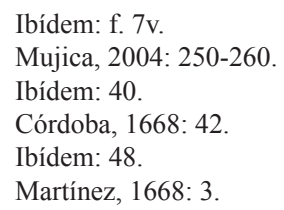




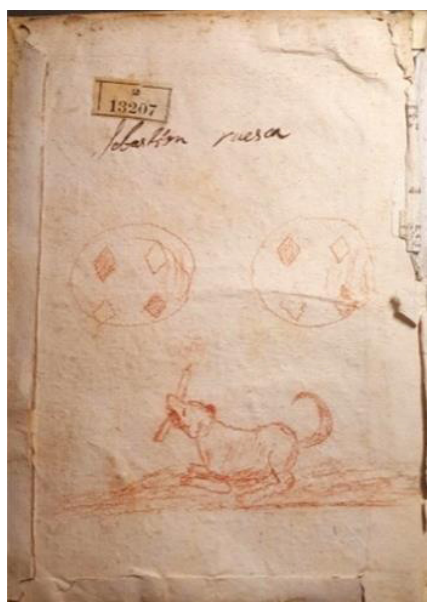

Figura 1. Dibujo en del Can de la Iglesia, parte trasera de la encuadernación de la obra Festivos cultos, célebres aclamaciones.

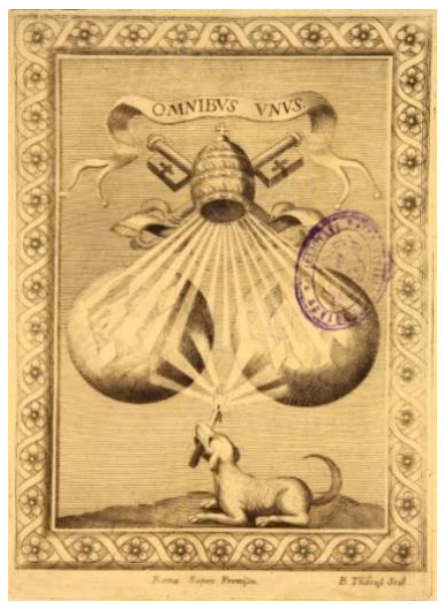

Figura 2. Thiboust, Benoit. "Omnibusunus". Grabado original, portada de la obra Festivos cultos, célebres aclamaciones.

Solamente faltaba un escrito del maestro general dominico, Juan Baptista de Marinis, para que se diese a conocer la beatificación al mundo. Ya desde el 10 de diciembre de 1667 -cuando se había obtenido de la Congregación de Ritos el decreto de beatificación-, Marinis envía al prior del convento dominico de Valladolid una carta para darle la noticia de la beatificación ${ }^{33}$. Se comienzan a extender las ceremonias festivas. Las cartas manuscritas del maestro de la Orden, unidas al breve papal, pasaron por el filtro y supervisión de la corte madrileña, que emitió el 14 de mayo de 1668 una real cédula donde se mandaba, por parte de la reina Mariana de Austria y su hijo menor don Carlos II, la celebración de fiestas públicas en honor de la beata Rosa de Lima en las tierras hispánicas. La real cédula se imprimió junto al breve y se incorporó en muchas obras escritas, para certificar que se cumplía con lo mandado por la corona. Predecía en su obra Córdoba y Castro la gloria de la Orden dominica en el orbe con esta nueva beata en proceso de canonización. Con ella el "Can de la Yglesia" iluminaría el mundo con su antorcha.

En aquella los Reyes caminaron para que naciesse, ni en este viage falto estrella, que hiciese la guia, por que el ardentissimo Can de la Yglesia, tronco Real y Santo de Guzman el bueno, desplegando los ardores de su zelo capitaneó sus hijos que fueron los primeros maestros y apóstoles a quien consignó Dios la conversion de la America donde hallo la actividad de su fuego, estendida esfera, su predicacion, espacioso campo, y la luz de su verdadera dosctrina nueuo Reyno de tinieblas que conquistar, pero con victoria tan segura como lo es la luz de la luz, que con solo dexarse ver triumfa de la más oscura noche ${ }^{34}$.

\footnotetext{
33 Carta manuscrita del maestro general dominico, Juan Baptista Marinis, al prior del convento de San Pablo de Valladolid. Roma, 10- XII-1667. Real Academia de la Historia [España] (en adelante RAH), 9/3600 (47) (2).

34 Córdoba, 1668: 2.
} 
Así lo dibujó e imaginó en la parte trasera de la encuadernación un lector de la obra a posteriori, señalando con cuatro rombos las cuatro partes del mundo (fig. 1) ${ }^{35}$, basándose en el grabado que Benoit Thiboust realizase en torno 1660, como portada de la obra original (fig. 2) ${ }^{36}$. Esta simbología zoomorfa de la Orden dominica estuvo muy presente en las fiestas en honor de Rosa de Lima, pues la figura de la terciaria se muestra como la consecuencia empírica de la empresa de evangelización dominica, católica e hispánica ${ }^{37}$. Así la imagen de la religiosa se esquematiza en una estrella, que por un lado refleja esa luz evangelizadora del Can de la Iglesia y por otro es estrella que guía a Lima y América hacia el camino de la santidad, como la estrella de oriente guió a los tres reyes magos. Las puertas de San Pedro fueron soporte de esta simbología:

[...] Tenían las armas del Papa, en medio de las del Rey Católico y las de la ciudad de Lima entre dos columnas con el Plus Ultra [...] el quartel de abaxo ocupaba el perro, que representa el mistico de la Yglesia, y el campo superior tres Coronas guiadas de una estrella ${ }^{38}$.

Roma no fue el único centro de propaganda americana en Europa. La Península Ibérica contaba con las ciudades ensoñadas y conocidas por los habitantes del resto del territorio imperial hispánico, con las que Lima y México siempre buscaron equipararse. Estas urbes peninsulares también se hicieron eco de las fiestas de su religiosa criolla. Una oportunidad para las urbes americanas de ser representadas en Europa, en este caso a través del clero regular dominico y de la nobleza limeña que viajó al Viejo Mundo, como el caballero peruano Campo y de la Rinaga ${ }^{39}$. Éste se encargó de mostrar cómo las ceremonias españolas -en concreto, las de Madrid- adoptaron el cariz de glorificación de la empresa de conversión patrocinada por la corona hispánica. Al mismo tiempo, como principal agente limeño en la corte ${ }^{40}$, marcó el acento sobre el carácter criollo y americano de la dominica beatificada:

[...] merecer en España con repetidos festejos la forastera Rosa, pues no ay ciudad, villa, o lugar grande, que no haya celebrado en religiosa y ostentosa competencia su Beatificación [...] Celébrala en buen hora Lustre y famosa España, centro de la fe sagrada, madre fecunda de santos, que hija tuya es, aunque nacida en Lima de padres criollos, pues en ella eternizas la más heroica hazaña de tus hijos, el más glorioso blasón de sus conquistas, el más arriscado timón de su valor, la más viva memoria de su lealtad, y el más encendido celo de su fe. Apláudela feliz, recíbela gustosa, que hoy vuelve de los extremos del Occidente a tus halados de madre si ayer la noble semilla que la floreció faltó del Oriente de tu Religión, como te profetizó Isaías ${ }^{41}$.

Tres urbes de gran simbolismo imperial destacaron en estas festividades: Madrid, Sevilla y Granada. Esta trilogía urbana peninsular se convierte en eje capital de las

\footnotetext{
Ibídem. Biblioteca Nacional de España [España] (en adelante BNE), Sala Cervantes: 2/13207.

36 Ibídem. Biblioteca de Fondo Antiguo de la Universidad de Sevilla [España], 235.3 “16”. Disponible en https:// archive.org/details/A022055.

Véase Vélez, 2007.

Córdoba, 1668: 13

Gálvez, 2014: 174-175.

Para profundizar en los agentes, véase Arias, 2020.

41 Campo, 1668: 29.
} 
relaciones de fiestas, que guardaron entre sus páginas los eventos acontecidos en España $^{42}$.

\subsubsection{Madrid}

Como capital cortesana de los Austrias españoles, Madrid se engalanó para recibir física y devocionalmente a Rosa de Lima y a los agentes de sus fiestas de beatificación. Mientras los habitantes de la Villa y Corte se preparaban para adecentar sus calles ante tal evento, desde El Callao viajan decenas de limeños, entre caballeros y religiosos, para patrocinar a su religiosa en Madrid ${ }^{43}$. Quizás uno de los más destacados fuese fray Antonio González de Acuña, procurador general de la provincia limeña de Santo Domingo para la canonización de Rosa de Lima, el cual a su paso por la corte madrileña en 1659 ya dejó constancia de esta nueva devoción americana, obteniendo de Felipe IV su apoyo a la causa.

Con el camino sembrado años antes por fray González de Acuña, a la llegada a la corte de los nobles y religiosos limeños en 1668, para las ceremonias de beatificación, éstos fueron acogidos por el Consejo de Indias, bajo el mando del conde de Peñaranda, que los representó en Madrid. Al igual que en Roma, serían los criollos del mundo andino los protagonistas de los festejos acaecidos en los conventos dominicos madrileños.

Entre aquella nobleza limeña encontramos a los caballeros Nicolás M. Campo y de la Rinaga -autor de la relación de fiestas Rasgo breve, disceño corto-, Ioseph Saavedra Bustamante y don Juan Bravo de la Maza. Éste último, nieto de Gonzalo de la Maza, se propuso promover el culto a la religiosa que había muerto en casa de su abuelo. Uno de los focos de las fiestas del convento de Santo Domingo el Real en Madrid, que estuvieron costeadas por esta nobleza limeña, la que con "santa vanidad", celebra "las glorias de su criolla", el "Sagrado Hércules de el Perú" que "supo poner a las columnas de la Iglesia en non plus ultra de las virtudes heroicas" $\mathrm{Y}$ es que para los criollos, la religiosa dominica era el "blasón y nueva corona de la Ilustre Ciudad de Lima", y el "refulgente esplendor del Nuevo Mundo"45. La obra de Campo y de la Rinaga expresa estas fiestas madrileñas como vía de promoción de la identidad americana, concretamente, de la élite criolla peruana. El interés del autor estuvo en destacar, nombre a nombre, a los sujetos limeños que participaron en las octavas festivas, entre los cuales también se encontraba él mismo.

El cuerpo de criollos quedó engrosado en estas fiestas con religiosos americanos que se trasladaron a la metrópoli para hacer gala de su más digna paisana. De este modo, encontramos a numerosos religiosos americanos protagonizando la octava de beatificación en Madrid como fray Ramón de Morales, de la Orden de la Merced, provincial de Santiago de Chile, o a Juan Isidoro Navarrete, canónigo limeño de la iglesia de Durango en Nueva España. Sobre todo destacaron los dominicos peruanos, como fray Pedro Lobo, natural de Trujillo (Perú), actuando como predicador en la octava en el día que asistió el canciller mayor de Indias y gobernador de su Real

42 Esta trilogía urbana ha sido seleccionada por la magnitud de sus fiestas y la relevancia de las ciudades. Otros autores dejaron constancia de sermones y fiestas de menor boato en los conventos dominicos de muchas ciudades peninsulares como Úbeda, Jaén, Valencia, Barcelona, Toledo, Burgos y Ciudad de Toro. Véase Parra, 1670.

43 Véase Bouza, 1995.

44 Campo, 1668: 1-4.

45 Mujica, 2004: 61-62. 
Consejo, el marqués del Carpio y Liche ${ }^{46}$. Su presencia, sus producciones escritas y sus predicaciones en Madrid fueron un constante alegato a la glorificación de América, Perú y del sector criollo, canalizado todo ello a través de la imagen de Rosa de Lima. Con estas fiestas se demostraba en Madrid el efecto evangelizador que había tenido la Monarquía española y, al mismo tiempo, se otorgaba protagonismo al virreinato del Perúu ${ }^{47}$.

El segundo lugar elegido para exaltar a la beata fue el convento de Santo Tomás. A diferencia de Roma y del resto de ciudades que veremos a continuación, en Madrid las procesiones no pudieron tener como eje la catedral, pero sí dispusieron de la ciudad y el palacio real. Primeramente se hicieron públicos los festejos que iban a dedicarse a una terciaria dominica, que se haría célebre en el católico pueblo del Manzanares. Según Campo y de la Rinaga, la religiosa "pobló de sus grandezas esta Corte, desafiando en públicos carteles de Relaciones diversas, fervorosos deseos de la devoción Española"48. Entre la ostentosa decoración, apareció una representación de América atípica. El Nuevo Mundo no se personificaba en un gentil indio, si no que aparece con vestido de túnica blanca, propia de los dominicos, donde el penacho de plumas y las flechas son sustituidos por rosas como emblema y alegoría de triunfo ${ }^{49}$. Se materializó aquí el fin último de la causa de canonización de Rosa de Lima: por parte de la élite criolla limeña, "blanquear" América e impulsar la idea de tierra civilizada que ya no sería mostrada con los atributos de los gentiles; y por otro lado, la Orden de los Predicadores buscó santificar la imagen alegórica de América, mostrándola ataviada con el hábito blanquinegro, publicitando en Europa el fruto recogido de su misión evangelizadora.

En Madrid se buscó llevar a cabo unas ceremonias del mismo calibre que Roma ${ }^{50}$. Desde hacía años, y especialmente desde 1630, los dominicos alcanzaron una gran capacidad de injerencia en los asuntos de la corte madrileña, pues fue la Orden la que obtuvo durante los años centrales del siglo la hegemonía en el cargo de confesor del rey y de la reina ${ }^{51}$. Un cargo que llevó a los dominicos a rivalizar con los padres ignacianos en la época -entre otros conflictos de diversa naturaleza- ${ }^{52}$. Ello les permitió tener a la corona española de su parte, abriendo el telón madrileño a los Andes y a su nueva beata.

Madrid se alumbró al igual que Roma con la luz dominica, "porque despabilando el hacha a su generoso Can, avivó la más segura luz de sus hijos, y salieron a todas luces del empeño. Intentó en la iglesia de Santo Tomás su celo más que octava maravilla" 53 . Sin embargo, las autoridades complicaron el espectáculo de fuegos artificiales, siendo crucial la capacidad de agencia de los indianos en Madrid para

\footnotetext{
46 Campo, 1668: 28.

47 Fernández Valle, 2013: 2089.

48 Ibídem: 3.

$49 \quad$ Fernández - Ollero - Rey, 2014: 6.

50 Parra, 1669. Introduce las fiestas de Roma y Madrid en la misma obra, equiparando ambas cortes en ostentación y boato en estas fiestas.

51 El dominico fray Pedro Álvarez de Montenegro fue confesor del rey Carlos II entre 1668-1675 y $1677-1678$. López Arandia, 2010: 26.

52 Las célebres disputas de pluma y tinta entre ambas órdenes no fueron óbice para el encuentro y participación de frailes de sendas religiones en ceremonias católicas de estas características. Los tres ejes de la rivalidad teológica-moral en la época entre jesuitas y dominicos fueron la Querella de los Ritos Chinos [Goicochea, 1971]; la polémica De Auxilis [Álvarez, 2009] y la cuestión de la Inmaculada Concepción [Broggio, 2013]

53 Campo, 1668: 44.
} 
conseguir que el presidente del Consejo de Castilla permitiese realizar fuegos en la Tela, a orillas del Manzanares. No obstante, ante las dificultades, el propio rey de las Españas, Carlos II, ordenó que los fuegos de artificio se realizasen en su real palacio. Los artífices Francisco López, Jospeh Martínez y Bartolomé de Zaragoza, sencillos artesanos de Madrid, hicieron gozar al pueblo madrileño, a los indianos y a la vista de sus reales altezas desde palacio. Así lo relató el limeño Campo y de la Rinaga:

Pero como nuestra Rosa nunca apeteció para su celebridad más tela que la del silicio, ni para su festejo más despejado sirio que el retiro corto de su jardín, su querido Esposo, aquel por quien los Reyes reinan, y en cuya mano están sus corazones, inspiró a nuestro Ángel Don Carlos (que guarde las edades de sus ascendientes todos) mandase que los fuegos de la Rosa se quemasen dentro de los términos de su Palacio, junto a sus reales jardines en la parte que llaman el picadero de la priora, para que no faltase aun celebrando su gloria, índice de su soledad en los jardines, memoria de su obediencia en la priora y padrón de sus mortificaciones en el Picadero ${ }^{54}$.

La última oración congratulatoria de las octavas la dio el dominico Gabriel Ramírez de Arellano: "Con majestuosa pompa ha sido aclamada estos días mi gloriosa santa Rosa de Santa María, a cuya fragancia de virtudes ha tributado aclamaciones la devoción christiana de los habitadores de esta magnífica corte de nuestro amado rey y señor Carlos II [...]"55. Sobre el Manzanares se reflejaron las primeras luces de un próspero y real festejo. Al frente de su balcón palaciego se situaban doña Mariana de Austria y don Carlos II:

Por frente de la ventana, en que asistió su Majestad, y a los extremos del paraje que llaman la Priora, se formaron dos hermosas y descolladas invenciones de fuego, cuya disposición si sirvió su horror de espanto al dispararse fue lisonja a los ojos de su hermosura ${ }^{56}$.

\subsubsection{Granada y Sevilla}

Tornando la vista hacia el sur peninsular, el nombre de la beata Rosa, "llegó a este paraíso de Europa, emporio de las grandezas de Españas, la ciudad de Granada"57. E1 13 de octubre de 1668 se tocaron las campanas de la torre de la iglesia del Real Convento de Santa Cruz. La Fortaleza Real de la Alhambra y los castillos hicieron salvas con su gruesa artillería, junto a repetidas cargas de arcabucería y mosquetería de sus nobles soldados. Las 25 parroquias y todos los conventos dieron "comisión a las lenguas de sus campanas para explicar sus regocijados afectos" $" 58$. Calle Nueva, plaza de los Girones o las orillas del Genil fueron el perfecto escenario para las luminarias y festejos del último día de la octava granadina.

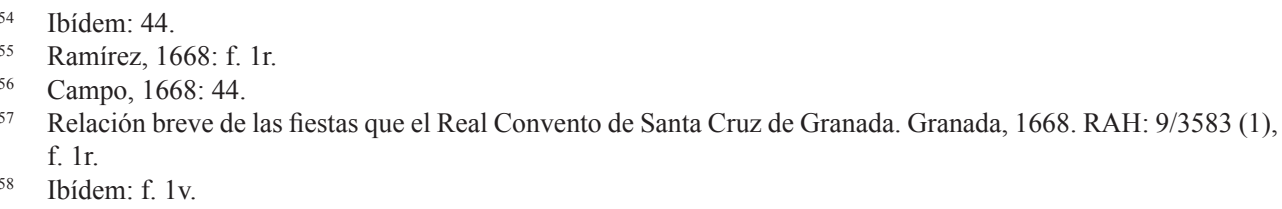


En el mismo año, el repique de las campanas de la Alhambra tuvo reflejos sonidos en la Giralda. Vibrantes luminarias pasaron del Genil al Guadalquivir. En la capital hispalense los centros festivos de la beatificación fueron el convento de San Pablo y Santo Tomás, el palacio arzobispal y la catedral, además del protagonismo de las procesiones por las calles de la urbe. En los talleres de la capital trabajaban artistas, como Murillo, reproduciendo imágenes de la religiosa, basadas en grabados flamencos con el fin de difundirlas por el Nuevo Mundo. El centro ceremonial se halló en el Real Convento de San Pablo, contando con presencias nobiliarias como la familia de los Guzmán. Un dominico de dicho convento, fray Bernardo López (Descripción de las sumptuosas fiestas, Sevilla, s.a.), tomó nota en su relación de fiestas sobre los acontecimientos.

El día 13 de octubre dio comienzo en Sevilla la octava, el mismo día que en Granada, de modo que el repique de las campanas de la provincia dominica de Andalucía fue al unísono.

Y ya cuando el brillador Planeta iba en el último desmayo de su lucir y ese Saphir hermoso comunicaba de sus Estrellas el resplandor; salió tan lucida la Giralda, que no escaseando sus luces, pareció que toda la Esfera del fuego estaba en sus capiteles. Diose fin a la fiesta, quedando con tanto ilustre la Dominica Familia, ya atenta a acción tan honorífica, agradeció fineza tan singular ${ }^{59}$.

El 4 de noviembre 1669 se daba la noticia en Sevilla de un milagro acaecido en el convento de la Madre de Dios. Una hermana de dicho convento, Sebastiana de Neve, era salvada de la muerte por intercesión de la beata Rosa a través de una de sus múltiples imágenes repartidas en los festejos y pintadas por los artistas. La información corrió como la pólvora y llegó hasta Barcelona en 1670, donde el taller de Mathevad se ocupó de imprimirla y repartirla por la ciudad condal ${ }^{60}$. Mientras tanto en Roma, la Congregación de Ritos seguía adelante con la canonización de la dominica limeña, siendo crucial la aparición de noticias milagrosas como la de la ciudad hispalense para culminar el proceso de canonización de la religiosa criolla.

\subsubsection{Lima y México}

A continuación, le tocó el turno a Lima, capital honrada con la virtud de la santidad americana. "Lima era la Roma santa en los templos", reza Buenaventura de Salinas y Córdoba. Razón no le faltaba, para la primera mitad del siglo XVII, el 10\% de la población limeña eran clérigos regulares, entre los cuales los dominicos tuvieron un importante peso aumentando en esas fechas el número de frailes y de conventos en el virreinato de Perú ${ }^{61}$. Lima vivió un periodo continuo de festejos en honor a su religiosa. La beatificación se celebró en abril de 1669; el patronazgo en agosto del mismo año por parte de la Orden de Santo Domingo, y entre diciembre de 1669 y enero 1670, tuvieron lugar las fiestas del cabildo de la ciudad en honor a su patrona. Las relaciones de Diego León Pinelo (Celebridad y fiestas, Lima, 1670) y de Gonzalo A. de Meneses y Arce (Ilustración de la Rosa del Perú, Lima, 1670) se hacen eco de ellas entre nuestro muestrario de fuentes.

\footnotetext{
López, s.a.: f. 130v.

Prodigioso milagro de Dios nuestro Señor obró. Barcelona, 1670. BNE, VE/1216/11.

Mujica, 2004: 3
} 
En 1669 llegaba a Lima la noticia de la beatificación, a manos del virrey Pedro Fernández de Castro, conde de Lemos, adjuntando el breve papal y la real cédula del 14 de mayo de 1668, expedida desde Madrid. El martes 30 de abril de 1669 se hicieron públicos en Lima sendos documentos de beatificación bajo palio, a través de una procesión encaminada desde el palacio virreinal hasta la catedral. La capital limeña se engalanó desde el 29 de abril de 1669, con las vísperas. Desde los torreones se anunció con chirimías y clarines el periodo festivo de octavas que estaba a punto de iniciarse.

Las calles de la ciudad estaban abarrotadas el martes 30 de abril de 1669, todo un público expectante para contemplar la primera procesión en honor a su beata dominica. La procesión llevaba como estandarte por las calles la real cédula y el breve de Clemente IX, junto a una imagen de la religiosa que fue trasladada desde el convento de Santo Domingo hasta el palacio virreinal, para acabar posteriormente en la catedral, donde tendrían lugar los primeros cultos en un sagrario profundamente exornado con imágenes y objetos de plata ${ }^{62}$. Presidió los actos litúrgicos en la catedral el arzobispo de Lima, Pedro de Villagómez.

Con motivo del nombramiento de la beata Rosa de Lima como patrona de capital peruana, volvieron a realizarse fiestas entre el 19 y el 26 de agosto de 1669 en la catedral, parroquias, conventos religiosos y monasterios limeños. El 19 agosto 1669, se comenzó con un octavario en el convento de Santo Domingo ${ }^{63}$. En el claustro había pinturas al óleo guarnecidas con ébano y marfil, espejos con cercos de corales, láminas de plata y plumas de pájaros. Un arte que se describe como propiamente americano, con las tradiciones artísticas del mundo amerindio, dando seña de identidad "local" a las fiestas limeñas respecto a las realizadas en Europa. Se elevó un altar en la capilla mayor del convento donde colocaron la imagen de bulto de la religiosa -puede que fuese la misma que presidió las fiestas de beatificación- y enriquecieron el centro de la iglesia con las reliquias de la religiosa dominica, que trasladaron los dominicos de su primer sepulcro -convento del Rosario- el viernes 23 de agosto del año de $1669^{64}$.

El octavario de patronazgo en el convento de los dominicos quedó ricamente descrito. Destaca el sexto día, que se reservó para la Universidad de San Marcos, y el séptimo para el Tribunal del Consulado, con unas espléndidas fiestas de vísperas donde el Consulado sacó seis carros a la calle con chirimías, precedidos de fuegos, con doce hombres armados delante "cada uno con montantes que se convirtieron después en penachos de luces" ${ }^{\prime 5}$. Estos carros triunfales solían ser de carácter alegóricos, en los cuales, con mucha frecuencia, se representaban metafóricamente a la Iglesia o a los continentes, entre otras. El Nuevo Mundo solía aparecer bajo la personificación del indio o también con figuras zoomorfas de caimanes, armadillos y papagayos, que con frecuencia se asociaban a la idea simbólica de América. En esta ocasión, el continente estuvo ataviado con atributos amerindios, reconocibles para la población local limeña. Una alegoría que se antoja versátil en función del público al que va dirigido si la comparamos con el cuadro de Madrid, ya descrito, donde América "santificaba" y transfiguraba su retrato europeo vestida con el hábito dominico. Adornos de plumas y oro también constituyeron la expresión física y estética de los

\footnotetext{
Meneses, 1670: 93.

León, 1670: 29.

Meneses, 1670: 107.

León, 1670: 49.
} 
desfiles festivos americanos del siglo XVII ${ }^{66}$. Llegados al octavo día festivo, el cabildo de la ciudad limeña junto a los alcaldes ordinarios y los capitulares cerraron la octava. El noveno día se guardó para la Compañía de Jesús, que haciendo acopio de sus victorias de santidad, unieron en sus sermones a san Ignacio y santo Domingo.

Para finalizar la octava hubo una nueva procesión con la imagen de Rosa de Lima por las calles de la ciudad. Delante iban cinco paraninfos y le seguían los sucesivos santos de su Orden. La presencia del componente musical era habitual con diversos instrumentos, donde, al mismo tiempo que se cantaba, se contaban los milagros y la vida de la religiosa al paso de la procesión, a través de los comediantes ${ }^{67}$. Los señores ministros togados ocupaban su lugar en la procesión: Real Audiencia, contadores del Tribunal de Cuentas, alcaldes ordinarios, capitulares, el cabildo de la ciudad, caballeros órdenes militares y demás nobleza. Todos iban dirección a la catedral, donde el virrey daría inicio a la procesión que acabaría en la Plaza Mayor. Las distintas órdenes religiosas esperaban en la plaza la llegada de la imagen de la beata y patrona ${ }^{68}$.

A más de las cinco de la tarde comenzó a salir la procesión de la santa Iglesia, capitaneada de algunas insignias y estandartes de cofradías, con sus santos, en curiosas andas, a quien seguían las comunidades de los padres de la Compañía de Jesús, con más de setecientos religiosos con quien se mezclaron los caballeros y devotos $[\ldots]^{69}$.

Cada día de la octava celebrada en Santo Domingo se cerró en la Plaza Mayor limeña con fuegos: "Y apenas hizo señas la noche, cuando inmensidad de cohetes reventando de apretados, llenaron de claridad la plaza y de cometas la región del aire" ${ }^{\prime 70}$. Esta vez era el Rímac, el río que vio crecer a la virtuosa criolla y llorar su muerte, el que contemplaba el gozo reflejado en sus aguas el cielo de iluminado de la Ciudad de los Reyes.

Tras haberse celebrado los actos litúrgicos, entre los días 20 y 27 de octubre, la Plaza Mayor volvió a ser el centro de los festejos por parte del cabildo en honor a su patrona entre noviembre de 1669 y enero de 1670. Varios días se corrieron toros (16, 20 y 23 de noviembre) y cañas (8 y 27 de enero de 1670). Se cerraron los soportales de la plaza con tablones y se dividieron los tablados. Se elevaron gradas para acoger a toda la multitud. Los virreyes presidieron los actos como representantes de su majestad Carlos II y el arzobispo Villagómez como delegado de Clemente IX ${ }^{71}$. Ello supuso el epílogo de las fiestas que se celebraron en Lima a la espera de la canonización de su religiosa. Desde entonces, las armas de la urbe limeña tendrían una nueva estrella sobre sus tres coronas. Una estrella que también alumbró a los indios que participaron en los festejos circenses acontecidos a finales de 1669 y principios de 1670 en Lima, ocupando su lugar correspondiente en el orden social colonial, como lo reflejan León Pinelo y Escalante Colombres.

El 11 de agosto de 1670 el pontífice Clemente X amplió el patronazgo atribuido a Rosa de Lima, y la declaró "Patrona Universal y Principal de toda América y dominios de España", convirtiéndose entonces en patrona de América y Filipinas. Por este

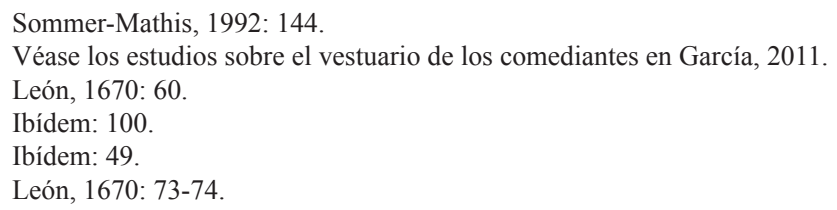


motivo llegó al puerto de El Callao un mes antes, en junio de 1670, proveniente de Roma, un conjunto escultórico de mármol de la beata, para que presidiese la iglesia del convento de Santo Domingo. Aquella escultura de mármol de Melchor Caffà fue la misma que pudieron admirar los romanos en la iglesia de Santa María sopra Minerva. Una imagen a la que rindieron culto fieles cristianos del Viejo y del Nuevo Mundo, cuyo simbolismo y devoción se transfiguró al ser venerada por el pueblo limeño, ajeno al patrón representativo de su dominica adormecida "a la italiana", siguiendo el modelo de Bernini. Mugaburu dejó testimonio del traslado:

Sacaron a las seis de la mañana del puerto del Callao la hechura de la Santa Rosa arriba referida, y dispararon toda la artillería, y a hombros de todos los vecinos del puerto del Callao la trujeron hasta la capilla real del palacio, sin que otra persona llegasen a cargar [...] Y en el camino arriba de la legua encontraron las mulas del señor virrey que iban a traer la santa hechura de Rosa, y la gente que la traía cargada apedrearon las mulas ${ }^{72}$.

Entre las relaciones de fiestas se puede observar que todas comparten el protocolo católico de realización de las octavas en beatificaciones y canonizaciones. Un símil entre las fiestas barrocas, que más allá de ser fruto de los cánones postridentinos, se dio también gracias a la circulación de testimonios escritos de las celebraciones de otras ciudades. Estas obras fueron tomadas por los escritores como referencias para llevar a cabo en su narración la comparación entre eventos y entre los centros urbanos. Así, la Plaza Mayor de Lima es comparada en las relaciones con la misma Roma y con la villa de Madrid en fiestas: “[...] que todo pareció dibujo de anfiteatro Romano, y comparándolo mejor, la plaza de Madrid en los festejos públicos"73. Al mismo tiempo se reseña la singularidad local e identitaria de las fiestas limeñas, subrayando que en la comitiva de los juegos de cañas entraron "seis Indios Chilenos, y guarnición plateada, y rodeando la plaza, quedaron en lugar destinado" 74 .

En México, por su parte, ya se conocía la noticia desde 1668, no obstante, se demoraron en su festejo. La última semana de septiembre de 1669 se dieron prisa y los dominicos de Oaxaca organizaron un octavario, según detalla Pedro de Arjona (Rosa mística del vergel florido, México, 1670). Entre el 25 y el 26 de septiembre destacaron los espectáculos de máscaras callejeras y una alegoría mitológica sobre la beata dominica, dispuesta en varios carros triunfales ${ }^{75}$. La sencillez de estas ceremonias se verá enriquecida tardíamente en 1671, cuando sea festejada por el cabildo de México. Hasta entonces, la devoción alcanzaba territorios fuera del dominio territorial de la corona española, gracias al concurso festivo y de impulso devocional que orquestaron los dominicos en cada sede de la Orden.

\subsubsection{De Portugal a Inglaterra}

El mundo portugués, como territorio que escapaba del dominio hispánico en estas fechas, también se hizo eco festivo del nombre de Rosa de Lima. Como corona cató-

\footnotetext{
Zugasti, 2013: 123.

León, 1670: 45.

Ibídem: 46.

Zugasti, 2013: 125.
} 
lica, la presencia de la Orden dominica en Portugal también era notable. Dominicos como Álvaro de Escobar Roubam ${ }^{76}$, prior de la parroquia de la iglesia de Águeda o Bento de Santo Tomás ${ }^{77}$, calificador del Santo Oficio y catedrático de Prima del Real Colegio de Santo Tomás, imprimen sermones -en Lisboa el primero y en Coímbra el segundo- que se pronunciaron en las fiestas de canonización.

Llegados a 1670, a través de diversas ordenanzas de los papas Clemente IX y Clemente X, comprendidas entre el 30 de octubre de 1669 y el 26 de agosto de 1670 , se va extendiendo la concesión de celebrar el día de Rosa de Lima el 26 de agosto. Dichas concesiones para la difusión de la devoción católica a esta beata, condujeron a que desde tierras lusas el escritor y embajador luso en Inglaterra y los Países Bajos, António Sousa de Macedo (Epitome panegyrico, Lisboa, 1670), instase a la reina de Inglaterra, doña Catalina de Braganza, a realizar una misa en la corte de Inglaterra en honor de la religiosa dominica.

Senhora. O Cuidado com que em Inglaterra se procurou, sem se conseguir, a traducção da Historia da Vida de S. Rosa Virgem Dominicana, que está impressa em Latim; a devação com que V. Magestade alcaçou Jubileo na sua Real Capella para o dia desta Santa; \& favor particular q[ue] della, por mão de V. Mag. recebi; me persuadirão a escrever na Corte de V. Magest. este Epitome, em lingia que se com[m]unicasse melhor, \& logo o dediquei a V. Mag. por offerta que mais the agradaria. Nem a Modestia que V. Mag. resplandece, permite as Dedicatorias / costumadas de floridos elogios; nem minhas obrigações se satisfazem com flores da terra, que todas secão, \& muitas não fructificão. Offereço a V. Mag. esta Rosa do Ceo, que não se murcha, \& he flor que dará fruto de alcançar de Deos para V. Mag. felicidades à satisfação de seus vasallos, que geralmente desejão a V. Mag. muitas, $\&$ he o mayor louvor de hũa grande Rainha. Eu a nenhum dou ventagem no animo de servir a V. Magestade como devo, por razões naturaes, \& civis, multiplicadas, \& muito notorias. Deos guarde a Real Pessoa de V. Magestade, \&c ${ }^{78}$.

En efecto, la misa fue celebrada. La reina hizo petición a la Santa Sede para la concesión de la celebración del oficio en honor a Rosa de Lima. El pontífice Clemente IX no dudó en dar respuesta concediendo el oficio y la indulgencia plenaria del siguiente modo:

Y auiendonos sido representado agora, de parte de tu Magestad, los grandes deseos que tienes, de que en tu Real Capilla, en que con licencia de la Sede Apostólica se celebra el Sacrosanto Sacrificio de la misa, se pueda rezar el oficio, celebrar la misa de la Beata Rosa, para mayor consuelo tuyo y edificación de los fiesele que habitan en esas regiones ${ }^{79}$

Lima y Londres, dos ciudades conectadas a través de la tinta portuguesa y el sucesor de san Pedro, como colofón del alcance geográfico que alcanzaron estas fiestas de beatificación, más allá de los límites atribuidos a la Monarquía Hispánica.

\footnotetext{
Escobar, 1670.

Santo Tomás, 1669.

Sousa, 1670: f. 1r.

Parra, 1670: 94
} 


\subsection{Fiestas de canonización en 1671}

Cuatro años después, Roma volvía a levantarse festiva por la beata Rosa de Lima. No hubo tiempo de terminar de observar los fuegos limeños, cuando en la Ciudad Eterna vemos a un nuevo pontífice, Clemente $\mathrm{X}$, promulgando la canonización de cinco religiosos el 12 de abril de 1671: Cayetano, Francisco de Borja, Felipe Benicio y Luis Beltrán, junto a Rosa de Lima. Las ceremonias tuvieron lugar entre abril y octubre de 1671. El procurador de esta causa sería el cardenal Altieri, nepote del papa Clemente X, con asistencia de su santidad en la ceremonia principal del 12 de abril de 1671 en San Pedro ${ }^{80}$.

Una relación de estas fiestas de canonización romanas destaca la relevancia y celebridad que adquirió esta ceremonia, donde acudieron a Roma dignidades de distintas partes de Europa, congregadas para honrar a los cinco santos. "En nombre de las Magestades del Emperador, Rey de España y República de Venecia. Señores embajadores de Portugal y Venecia, príncipe don Gaspar y don Ángel Altieri, el señor Domingo Orsino, duque de Gravina; sobrinos de su Santidad". A ello hemos de añadirle la asistencia de don Lorenzo Colonna, duque de Paliano y condestable del reino de Nápoles. También asistieron cuatro embajadores de Bolonia y el gobernador de Roma, monseñor Bevelagua ${ }^{81}$.

Los fuegos en Roma sirvieron para enaltecer y llevar a las alturas el nombre de la religiosa, ahora santa, "por mejor decir si la estrella es Rosa en el campo azul del Cielo, la Rosa es estrella en el campo verde de la Tierra" ${ }^{82}$. El 4 de agosto de 1671 el pueblo romano volvió a concentrarse en Santa María sopra Minerva para ver el gran retablo en honor a Luis Beltrán y a Rosa de Lima, asistiendo a la ceremonia de los frailes blanquinegros. El dominico Giuseppe Paglia describe así su fachada: ${ }^{83}$

[...] che nuovo Sole del Cielo Dominicano saluva ad accrescere splendori alle sfere superne; e nell' altra vedevasi la Santa che era coronata dal redentore Signor Nostro con un fiorito serto di Rose, e meritamente giaché eratutta cinta di sìne di mortificationi ${ }^{84}$.

Las fiestas de canonización también tuvieron desarrollo con gran esplendor en Sevilla, coincidiendo con la canonización de Fernando III. El predicador provincial de Andalucía fue el encargado de pregonar la bula papal a todos los priores e intermedió con el cabildo de la catedral y el resto de tribunales para que asistiesen a la ceremonia de inauguración. La bula de canonización de la religiosa peruana se hizo pública por las distintas autoridades eclesiásticas y frailes dominicos en diversos templos ${ }^{85}$.

Sevilla proyectó con estas fiestas completar la imagen de santidad que ya aportó en vida la propia religiosa criolla en la Ciudad de los Reyes. La capital hispalense se volcó en favorecer el proceso de canonización de la dominica criolla, como si fuese una vecina más nacida en las orillas del Guadalquivir. Tal es así que en ella

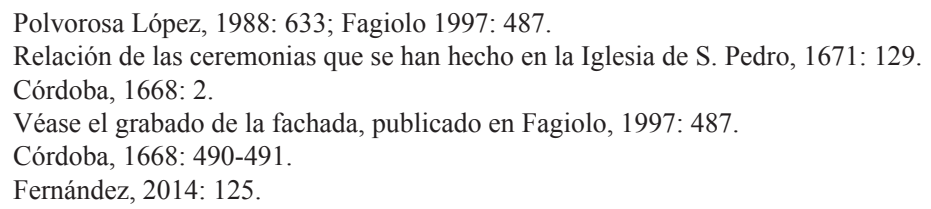


acontecen los principales milagros de la imagen de la Rosa de Lima, completando la imagen virtuosa de la religiosa. Todo un proceso de propaganda que contó con la intervención de clérigos, prelados, médicos, teólogos e incluso con el propio arzobispo hispalense, encargado de certificar los milagros que acontecían ${ }^{86}$.

Por último, queda constancia de las fiestas de canonización en Madrid a través de una relación de fiesta escrita en romance, conservada en la Biblioteca del Museo Nacional del Prado. La procesión que se llevó a cabo en la Villa y Corte tuvo lugar el 27 de septiembre de 1671, con san Luis Beltrán y santa Rosa de Lima como protagonistas. Muy profusa es la relación acerca de la decoración, destacando la descripción del palacio real, que no hacen otras relaciones de fiestas madrileñas: "El Palacio del gran Carlos/ con ayrosas prevenciones,/ colgaduras desprendía/ de los dichosos balcones./ Un Altar Atlante suyo/fue, que en términos veloces/ cifró la gloria de cuantos/ apostaron ambiciones" 87.

Las vísperas estuvieron capitaneadas por clarines para anunciar la procesión y los días de octavas. La noche de aquel 26 de septiembre hubo luminarias: "A su aviso son los fuegos/ Lucientes emulaciones, / que al más impensado día/ Ofrecen transformaciones./De la variedad de luces/ de antorchas, y de faroles/ estrellado firmamento/ en la tierra se compone" 88 . Al llegar el día de la procesión, Madrid amanece festiva, y entre el cortejo que caminaba hacia el convento de Santo Tomás no sólo vemos a las autoridades eclesiásticas y civiles de la villa o a los frailes dominicos, sino también nos volvemos a encontrar con la célebre presencia peruana, actuando como agentes de este evento, al igual que se identificaban en la beatificación. Constantemente aprovecharon sus predicaciones y sermones en las fiestas de canonización para resaltar alegóricamente su pertinencia al Nuevo Mundo y equiparar Lima a las homólogas metrópolis europeas. Exaltan con orgullo su seña de identidad a través de un carro triunfal, en el corazón de la capital imperial, costeado por los propios caballeros indianos y cargado de simbolismo:

Del Carro del Sol más dócil,/ que siendo nevados Alpes, eran ardientes Etontes./ En el superior lugar/ la Rosa de los amores/ del mas soberano Dios/ por timbre se reconoce./ Luisa la mano derecha/Cándido el pecho descoge,/ y Domingo a la siniestra/ alienta veneraciones./ A la redondez del Carro/ con flechas, y con arpones, carcajes y plumas iban/ de las Índicas Naciones./ Los Caballeros Indianos/ fueron deste Carro móvil,/ que a expensas de su caudal le dispusieron conformes./ Que aunque a igualar no llegó/ de su afecto a los ardores,/ su devoción llegar puede/ a más ilustres acciones ${ }^{89}$.

\section{3. Últimas luces festivas en México y Manila}

México ${ }^{90}$ se trata de un caso excepcional en la celebración de estas fiestas. Aquí se constata aún la celebración de la beatificación de la religiosa dominica de manera

86 Ibídem: 135-136.

87 Célebre culto al mayor triunfo. S.1. 1671. Biblioteca Museo Nacional del Prado (en adelante BMNP), Cerv/789, f. $1 \mathrm{v}$.

88 Ibídem: f. 1 r.

89 Célebre culto al mayor triunfo. S.1. 1671. BMNP, Cerv/789, f. 2 v.

90 Algunos autores han visto a Antonio de Morales Pastrana el único autor de la relación de las fiestas de beatificación en México, como la reciente tesis de Ybeth Arias. No obstante, otros autores de la época aportan datos 
tardía entre marzo y abril de 1671, con misa mayor en la catedral, procesiones, fuegos, luminarias y certámenes poéticos. El retraso en la celebración de estas fiestas, que nos detalla Morales Pastrana en su obra Solemne plausible festiva pompa (México, 1671 $)^{91}$, quizás fue debido a la inestabilidad política del virreinato mexicano, o bien, a la escasa asimilación del corpus identitario y simbólico que encerraba la figura de Rosa de Lima por parte del sector criollo mexicano. Los habitantes de México, con gran diversidad étnica en su sociedad, compuesta por sujetos de múltiples orígenes geográficos, festejaron a Rosa de Lima con la misma categoría, fervor y regocijo que en todas las metrópolis citadas. El octavario contó con misa y sermón diarios, empezando con las vísperas el sábado 11 de abril y concluyendo el domingo 19. El 25 de abril tuvo lugar una comedia de santos con la vida de la beata y concertado un certamen poético. El 30 de agosto de 1671 se vieron los últimos repiques de campanas en México con el octavario festejado por los dominicos del convento mexicano de Santa Catalina de Siena. Escalante Colombres y Mendoza da cuenta de ello en su Beatificación de la virgen gloriosa (México, 1672) ${ }^{92}$.

Tras pasar por México, la celebración de la canonización de la terciaria dominica, junto a san Luis de Beltrán, llegó lenta pero contundentemente a Filipinas. A la altura de 1676, la noticia de la beatificación y confirmación del culto en 1671 de los dos miembros de la Orden, desembarcó en Manila. El colegio y Universidad de Santo Tomás, que regentaban los dominicos, estipularon tres días de fiestas, entre el 23 y el 25 de noviembre de 1676. El provincial de la Orden en Manila, fray Felipe Prado (Sagrada fiesta, tres veces grande, Manila, 1677), se encargó de resumir los actos festivos en una relación recuperada por el historiador Zugasti ${ }^{93}$. Una hagiografía de la dominica, impresa en el taller que se ubicaba en las casas de la Compañía de Jesús, da una muestra viva de estos festejos. Gracias a ella sabemos que fue el gobernador de Filipinas, Manuel de León (1668-1677), quien habría actuado en calidad de intermediario oficial para ordenar la organización de los festejos. ${ }^{94}$ Esta última hagiografía datada a fines del siglo XVII, en 1697, cierra con su fecha de publicación un amplio recorrido espacio-temporal de unas fiestas religiosas, que dejaron un cerco de devoción universal tras de sí.

\section{Conclusiones}

La revisión historiográfica y la relectura de las fuentes primarias de este estudio de caso, desde un nuevo enfoque global, permite apreciar el nivel de influencia y actividad que Roma y la Monarquía Hispánica fueron capaces de alcanzar, no sólo desde un contexto europeo, sino desde los territorios coloniales, que se convierten en núcleos irradiadores de patrones culturales católicos-hispánicos, consolidados en el siglo

de festejos previos como el realizado por los dominicos de en el convento de Oaxaca en 1669 o Colombres y Mendoza en su obra impresa en México en 1672.

91 Morales, 1671: 19.

92 Escalante Colombres, 1672. Véase la relevancia de la Tercera Orden dominica en México a partir de la beatificación de Rosa de Lima en Jiménez, 2017: 150-153.

93 Zugasti, 2013: 126-127. La obra que cita Zugasti de Felipe Prado no ha podido ser consultada debido a la imposibilidad de su acceso al conservarse en la Orden dominica de Filipinas.

94 Carta del presidente Juan Pérez de Guzmán. Manila, 31-X-1669. Archivo General de Indias (en adelante AGI) [España], Panamá, 24, R.2, n.33. Se certifica en este documento el cumplimiento de la real cédula y breve papal por parte del presidente de Filipinas. 
XVII. Ahora sí, el espacio americano, siempre visto como un mundo "corruptible" y periférico, quedaba santificado. Por consiguiente, se puede concluir que fueron tres poderes los que facilitaron la globalidad del culto a Rosa de Lima: la Monarquía Hispánica, la Iglesia y la Orden de los Predicadores. La conjugación de estos, proporcionó los elementos básicos para que la maquinaria festiva dominica funcionase con éxito.

La Monarquía Hispánica, contemplada como poder territorial, proporcionó el espacio donde se desarrollaron las fiestas de beatificación y canonización de la dominica criolla. El territorio hispánico se observa como el tablero favorable a la movilización multidireccional de los agentes de las fiestas, de los objetos devocionales que participaron en las ceremonias y de los escritos que propagaron las noticias festivas, sorteando las distancias. En segundo lugar, la Orden de los Predicadores aportó el poder institucional desde los conventos coloniales, el generalato de Roma y las sedes conventuales peninsulares. Desde que llegasen los primeros dominicos a América en 1510 para misionar, dicha Orden fue extendiendo su capacidad de influencia y gestó toda una red institucional entre los siglos XVI y XVII, que permitió una administración coordinada de todas sus sedes repartidas por el planeta. Los sujetos de este tejido institucional fueron los frailes dominicos, destacando los frailes limeños, que actuaron como principales agentes promotores del proceso de canonización y de las fiestas organizadas en honor de su virtuosa dominica peruana. Una institución religiosa cuyas sedes y miembros sobrepasaban los límites territoriales de la Monarquía Hispánica, diluyendo las fronteras de aquel espacio donde se desarrollaron los principales eventos festivos.

El telón de fondo lo puso el credo católico. El catolicismo de la Alta Edad Moderna se convierte en un elemento básico para entender este fenómeno festivo de naturaleza socio-cultural y política. Este catolicismo, a través del proyecto evangelizador de tierras de gentiles, buscó la construcción de una uniformidad confesional. No obstante estos pretendidos mecanismos de homogeneidad cultural y religiosa no fueron exitosos en su totalidad. Como consecuencia, en cada ceremonia festiva analizada, se pueden encontrar elementos de una expresión cultural propia, un "catolicismo local". Cada territorio vivió las fiestas de un modo particular, como sucedió en América, donde la exteriorización de su catolicismo fue la más viva expresión de su identidad criolla, con elementos propios del mundo mestizo amerindio. Expresiones de identidad que se vieron en el territorio colonial americano y en las propias fiestas que organizaron los caballeros y dominicos limeños en Madrid y Roma, reflejando ello un "catolicismo plural" altomoderno ${ }^{95}$.

En definitiva, Rosa de Lima se acaba convirtiendo en un elemento imperial, "patriótico", católico y propagandístico, que debe su alcance geográfico a la floreciente "primera mundialización", que hicieron efectiva los imperios ibéricos, contando con las órdenes religiosas y el catolicismo romano. Una dominica originaria de América, que con su vida y muerte dio el asunto a este espacio colonial para santificarse así mismo por medio de sus élites criollas, que supieron orquestar una labor de propaganda identitaria, con el fin de reivindicar la relevancia del Perú en el mundo hispánico del siglo XVII.

Los imperios ibéricos, el tejido institucional dominico y la sede pontificia, crearon el escenario perfecto para desarrollar esta obra festiva estrenada en Roma y clausurada en Manila, viendo cada noche, en las principales plazas urbanas, un cielo alumbrado por luminarias en todo su esplendor barroco.

95 Véase Palomo, 2018 y 2013. 


\section{Referencias bibliográficas}

Albornoz, Diego F. Breve relación de la solemnísima fiesta de la beatificación [...]. Granada: Baltasar de Bolívar, 1668.

Arias, Ybeth. "Integración de un sistema devocional indiano en la Monarquía Hispana. El culto de santa Rosa de Santa María en las ciudades de Lima y México, 1668-1737’. Tesis Doctoral, El Colegio de México, 2019.

- "Los agentes de santa Rosa de Santa María. Gestores, divulgadores y devotos de la santa indiana en el Viejo y el Nuevo Mundo, siglo XVII". Transhumante. Revista de Historia Social, n 16 (2020), 82-103.

Betrán Moya, José L (ed.). La Compañia de Jesús y su proyección en el mundo hispánico durante la Edad Moderna. Madrid: Sílex, 2010.

Bouza Álvarez, Fernando. "Cortes festejantes: fiesta y ocio en el cursus honorum cortesano". Manuscrits, $\mathrm{n}^{\circ} 13$ (1995), 185-203.

Broggio, Paolo. “Teologia, ordini religiosi e rapporti politici: la questione dell'Inmacolata Conceziones di Maria tra Roma e Madrid (1614-1663)”. Hispania Sacra, nº 65 (2013), 255-281.

Callado Estela, Emilio. "Por Dios y por el rey: los virreinatos del arzobispo de Valencia fray Juan Tomás de Rocabertí (1678-1679 y 1683)". Estudis: Revista de Historia Moderna, nº 30 (2007), 157- 182.

Campo y de la Rinaga, Nicolás M. Rasgo breve, disceño corto[...]. Madrid: Mateo de Espinosa y Arteaga, 1668.

Cardim, Pedro - Herzog, Tamar - Ruíz Ibáñez, José Javier - Sabatini, Gaetano. Polycentric monarchies: how did early modern Spain and Portugal achieve and maintain a global hegemony? Brighton: Sussex Academic Press, 2012.

Carrió-Invernizzi, Diana. El gobierno de las imágenes. Ceremonial y mecenazgo en la Italia española de la segunda mitad del siglo XVII. Madrid-Frankfurt am Main: Iberoamericana-Vervuet, 2008.

Checa Cremades, Fernando -Fernández-González, Laura (eds.). Festival culture in the world of the Spanish Habsburg. Franham: Ashgate, 2015.

Conrad, Sebastian. Historia Global. Una nueva visión para el mundo actual. Barcelona: Crítica, 2017.

Córdoba y Castro, Francisco. Festivos cultos, célebres aclamaciones... Roma: Nicolás Ángel Tinas, 1668.

Ditchfield, Simon. "Thinking with Saints. Sanctity and Society in the Early Modern World". Critical inquiry, $\mathrm{n}^{\circ} 3$ (2009), 552-584.

- "De-centering the Catholic Reformation: papacy and peoples in the Early Modern World", Archiv für Reformationsgeschichte, $\mathrm{n}^{\mathrm{o}} 101$ (2010), 186-208.

Escalante Colombres y Mendoza, Manuel. Beatificación de la virgen gloriosa Rosa de Santa María. México: Rodríguez Lupercio, 1672.

Escobar Roubam, António. Sermam da Beatificaçam da S. Mare Rosa de S. Maria...Lisboa: Antonio Craesbeeck de Mello, 1670.

Fagiolo dell'Arco, Maurizio. La festa barroca. Roma: Edizioni de Luca, 1997.

Fernández Valle, Ma Ángeles. "El poder de la santidad. Presencia peruana en la Corte, en razón de la beatificación de Santa Rosa de Lima”. En Las artes y la arquitectura del poder, editado por Mínguez Cornelles, Víctor. Castellón de la Plana: Universitat Jaume I, 2013, 2087-2102.

— "El poder de las imágenes: Santa Rosa de Lima en la capital hispalense". En Arte y patrimonio en España y América, editado por Fernández Valle, $\mathrm{M}^{\mathrm{a}}$ Ángeles - Ollero Lobato, 
Francisco - Rey Ashfield, William. Montevideo: Universidad de la República (Uruguay), 2014, 119-139.

Fernández Valle, Ma Ángeles - Ollero Lobato, Francisco - Rey Ashfield, William. Arte y patrimonio en España y América. Montevideo: Universidad de la República (Uruguay), 2014.

Ferrer de Valdecebro, Andrés. Historia de la maravillosa y admirable vida [...]. Madrid: Pablo de Val, 1666.

Flores Araoz, José. Santa Rosa de Lima y su tiempo. Lima: Banco de Crédito, 1995.

Gálvez Peña, Carlos M. “«El mejor arbitrio, el sermón». Discurso religioso y representación política en el Perú del siglo XVII”, Anuario de Estudios Americanos, no 71 (2014), 171-197.

García García, Bernardo. "Máscaras en el vestuario de representación (1561-1606). Hatos de comediantes, contratación de fiestas y alquiler de accesorios". En Máscaras y juegos de identidad en el teatro español del Siglo de Oro coordinado por Lobato, Ma Luisa. Madrid: Visor Libros, 2011, 37-58.

Goicoechea, Margarita-Vega y de Luque, Carlos-Luis de la. "Planteamiento de una comprensión del espíritu chino: la querella de los ritos y Domingo Fernández de Navarrete". Boletín de la Asociación Española de Orientalistas, no 7 (1971), 75-96.

González de Acuña, Antonio. Rosa mística, vida y muerte de Santa Rosa de S. María [...]. Roma: Nicolás Ángel Tinas, 1671.

Graziano, Frank. "Santa Rosa de Lima y la política de canonización”, Estudios y Debate, no 37 (2002), 16-27.

- Wounds of love. The mystical marriage of Saint Rose of Lima. New York: Oxford University Press, 2004.

Gruzinski, Serge. Las cuatro partes del mundo. Historia de una mundialización. México: Fondo de Cultura Económica, 2010.

Hampe Martínez, Teodoro. "Los testigos de Santa Rosa, una aproximación social a la identidad criolla en el Perú colonial". Revista Complutense de Historia de América, n ${ }^{\circ} 23$ (1997), 113-136.

Hansen, Leonardo. Vida admirable y muerte preciosa de la venerable Madre Soror Rosa de Santa María[...].Valencia: Jerónimo Vilagrasa, 1665.

Hsia, Ronnie Po-Chia - Palomo, Federico. "Religious identities in the Iberian Worlds (15001700)". En The Iberian World, 1450-1820, editado por Bouza, Fernando - Cardim, Pedro - Feros, Antonio. Abingdon-NewYork: Routledge, 2020, 77-105.

Jiménez Jimémez, Ismael. "Las cofradías de indígenas de Santa Rosa: Fundaciones y propagación en la archidiócesis de lima durante la década de 1670". Temas americanistas, $\mathrm{n}^{\circ}$ 39 (2017), 146-182.

León Pinelo, Diego. Celebridad y fiestas[...]. Lima: s.i., 1670.

López, Bernardo. Descripción de las sumptuosas fiestas[...]. S. 1., s.i., s.a.

López Arandia, María A. "Dominicos en la corte de los Austrias: el confesor del rey", Tiempos Modernos, $\mathrm{n}^{\mathrm{o}} 20$ (2010), 1-30.

Martínez, Nicolás. Oración panegírica de la beata Rosa de Santa María [...]. Roma: Nicol Ángel Tinas, 1668.

Meneses y Arce, Gonzalo A. de. Ilustración de la Rosa del Perú [...]. Lima: Juan de Quevedo, 1670.

Morales Pastrana, Antonio. Solemne, plausible, festiva pompa[...]. México: Francisco Rodríguez Lupercio, 1671.

Mujica Pinilla, Ramón. Rosa Limensis. Mística, política e iconografía en torno a la patrona de América. México: Fondo de Cultura Económica, 2004. 
Palomo del Barrio, Federico. "Cultura religiosa, comunicación y escritura en el mundo ibérico de la Edad Moderna”. En De la tierra al cielo. Líneas recientes de investigación en Historia Moderna,vol. I,coordinado por Serrano Martín, Eliseo. Zaragoza: Institución Fernando el Católico, 2013, 57-88.

- "Un catolicismo en plural: identidades, disciplinamiento y cultura religiosa en los mundos ibéricos de la Edad Moderna". En Poder, sociedad, religión y tolerancia en el mundo hispánico, de Fernando el Católico al siglo XVII, vol. I., coordinado por Serrano Martín, Eliseo - Gascón Pérez, Josep. Zaragoza: Institución Fernando el Católico, 2018, 193-217.

Parra, Jacinto de la. La bienaventurada Rosa peruana de S. María[...]. Madrid: Francisco Nieto, 1669.

- Rosa laureada entre los santos. Madrid: Estado eclesiástico en la corona de Castilla y León, 1670.

Polvorosa López, Tomás, "La canonización de Santa Rosa de Lima a través de Bullarium Ordinis FF. Praedicatorum". En Actas del I Congreso Internacional sobre los Dominicos y el Nuevo Mundo. Madrid: Deimos, 1988, 604-637.

Sommer-Mathis, A. El teatro descubre América. Fiestas y teatro en la casa de Austria. Madrid: Editorial Mapfre, 1992.

Vargas Machuca, Juan. La Rosa del Perú [...]. Sevilla: Juan Gómez de Blas, 1659.

Vélez, Elio. "Santa Rosa de Lima y la simbología sacro imperial. Lectura desde la épica, la corografía y la iconografía (siglos XVII-XVIII)". Lexis, no 31 (2007), 357-389.

Zugasti Zugasti, Miguel. "Santa Rosa de Lima, una santa del pueblo con sus fiestas y comedias para el pueblo". En Teatro español de los Siglos de Oro. Dramaturgos, textos, escenarios, fiestas, coordinado por Díez Borque, José M. Madrid: Visor Libros, 2013, 117-154. 
